\title{
Effects of dried thyme (Thymus vulgaris L.) leaves on performance, some egg quality traits and immunity in laying hens
}

\author{
Sakine YALÇIN ${ }^{1, \mathrm{a}, \bowtie}$, Handan ESER ${ }^{2, \mathrm{~b}}$, İlyas ONBAŞILAR ${ }^{3, \mathrm{c}}$, Suzan YALÇIN ${ }^{4, \mathrm{~d}}$ \\ ${ }^{1}$ Ankara University, Faculty of Veterinary Medicine, Department of Animal Nutrition and Nutritional Diseases, Ankara; ${ }^{2}$ Bolu Abant \\ İzzet Baysal University, Faculty of Agriculture and Natural Sciences, Department of Poultry Farming, Bolu; ${ }^{3}$ Hacettepe University, \\ Transgenic Animal Technology Application and Research Center, Ankara; ${ }^{4}$ Selçuk University, Faculty of Veterinary Medicine, \\ Department of Food Hygiene and Technology, Konya, Turkey. \\ aORCID: 0000-0001-8640-2729; bORCID: 0000-0002-7617-6059; ' $O R C I D: 0000-0002-1464-4654$; \\ dORCID: 0000-0002-3937-6705
}

\author{
$\triangle$ Corresponding author: sayalcin@ ankara.edu.tr \\ Received date: 19.12.2019- Accepted date: 16.03 .2020
}

\begin{abstract}
The aim of the present study was to investigate the usage of thyme leaves and its effects on performance, some egg quality traits and humoral immunity in laying hens. A total of 108 laying hens aged 36 weeks were randomly assigned to three dietary groups for 16 weeks. Dried and ground (Thymus vulgaris L.) thyme leaves were used at the level of 0,1 and $2 \%$ in the diets of groups. Feed intake, body weight, egg production, egg weight and egg quality characteristics were not affected by dietary thyme supplementation. Thyme supplementation at $2 \%$ resulted in beneficial effects in laying hens due to the lowering of yolk cholesterol and total saturated fatty acids concentration while increasing omega- 3 fatty acids. Furthermore, the yolk malondialdehyde, blood serum cholesterol and triglycerides levels were reduced and antibody titers against SRBC were increased with $2 \%$ thyme supplementation. In conclusion, the results showed the antioxidative and hypolipidemic effects of thyme supplementation in laying hens along with improved humoral immune response without any negative effects on performance and egg quality characteristics.
\end{abstract}

Keywords: Egg quality traits, immunity, laying hen, performance, thyme.

\section{Kurutulmuş kekik (Thymus vulgaris $\mathbf{L}$.) yapraklarının yumurta tavuklarında performans, bazı yumurta kalite özellikleri ve bağışıklık gücüne etkisi}

Özet: Bu araştırma yumurta tavuğu rasyonlarında kekik yaprağı kullanımının performans, bazı yumurta kalite özellikleri ve humoral immunite üzerine etkilerini belirlemek için yürütülmüştür. Toplam 108 adet 36 haftalık yumurta tavuğu 16 haftalık deneme için 3 deneme grubuna ayrılmıştır. Kurutulmuş ve ögütülmüş kekik (Thymus vulgaris L.) yaprakları \%0, 1 ve 2 düzeyinde grup karma yemlerinde kullanılmıştır. Yem tüketimi, canlı ağırlık, yumurta verimi, yumurta ağırlığı ve yumurta kalite özellikleri karma yemde kekik bulunmasından etkilenmemiştir. Kekiğin \%2 düzeyinde ilavesi yumurta sarısında kolesterol ve toplam doymuş yağ asidi konsantrasyonunu azaltıp omega-3 yağ asitlerini artırarak yararlı etkiler sağlamıştır. Ayrıca \%2 kekik ilavesi ile yumurta sarısı malondialdehid konsantrasyonu, kan serum kolesterol ve trigliserit düzeyleri azalmış ve SRBC'ye karş1 antikor titresi artmıştır. Sonuç olarak yapılan çalışmada rasyonlara kekik ilavesinin yumurta tavuklarında performans ve yumurta kalite özellikleri üzerinde olumsuz etki yaratmadan humoral immun yanıtı iyileştirmesi ile birlikte antioksidatif ve hipolipidemik etkiye sahip olduğu gösterilmiştir.

Anahtar sözcükler: İmmunite, kekik, yumurta kalite özellikleri, yumurta tavuğu, performans.

\section{Introduction}

Today many feed additives including prebiotics, probiotics, organic acids, phytogenic substances and aromatic plant extracts are commonly used in animal production as an alternative to antibiotics to improve health and performance. Especially aromatic plants and extracts have attracted considerable attention as performance enhancers because of their antioxidant and antimicrobial properties (12), digestion stimulator potential (31), immune enhancer and antiinflammatory potential $(24,32)$ and to produce functional food decreasing cholesterol content while increasing beneficial nutrients in foods $(17,39)$.

Thyme (Thymus vulgaris L.) is a member of Lamiaceae family, an aromatic herb used extensively in food to add a distinctive aroma and flavour. Thyme is among the main herbs used in the food and pharmaceutical industries. Thyme essential oil components are used as 
raw material in perfumery and cosmetics due to their special and characteristic aroma (32). Some Thymus spp. are used for antihelminthic, antiseptic, expectorant, antispasmodic, antifungal, antimicrobial, immunostimulants, hypocholesterolemic, antioxidative, antiviral, carminative, sedative and diaphoretic effects in folk medicine $(24,32)$.

Some researchers $(23,46,48)$ reported the beneficial effects of dietary thyme in poultry. Beneficial effects could be related to thyme essential oils. Dried thyme contains 1 to $2.5 \%$ essential oil. Thymus vulgaris essential oil is a mixture of monoterpenes, mainly thymol and its phenol isomer carvacrol. Additionally, phenolics such as caffeic acid, p-cymene-2,3-diol and some biphenylic and flavonoid compounds like flavonoid glycosides, flavonoid aglycones were shown to exhibit antioxidative effect and other beneficial effects for poultry $(24,32,44)$.

Hashemipour et al. (29) reported that phytogenic product having thymol and carvacrol improved performance, digestive enzyme activities, antioxidant enzyme activities and immune response and retarded lipid oxidation in broilers. Migliorini et al. (43) stated that the supplementation of oregano essential oil had beneficial effects on bird health without any side effects and concluded that there is a need for more studies to evaluate wheather oregano essential oil may enhance egg quantity and quality. Du et al. (22) concluded that the dietary supplementation of 60,120 and $240 \mathrm{mg} / \mathrm{kg}$ essential oil containing 25\% thymol and 25\% carvacrol improved the intestinal histomorphology, decreased the inflammatory response and enhanced the spesific immune response in the $C$. perfringens-challenged broiler chickens. Thyme extracts are recommended to improve the performance and fatty acid profiles in the yolk of eggs in layers (49).

In most parts of the world, the herbal leaf waste after the volatile oil extraction is not utilized properly and generally remains unused. Other than the essential oils, the usefulness of many other bioactive compounds present in herbal leaves waste is revealed in various studies. Considering this, the benefits of using the herbs as a whole should be considered while feeding the poultry with different herbal additives.

The effects of dietary supplementation of dried thyme leaves in poultry, particularly as a direct and less expensive route of herb supplementation, are understudied and little published data is available (11, 23, 27, 28, 48). Florou-Paneri et al. (27) investigated the use of oregano herb versus oregano essential oil to increase the oxidative stability of turkey meat and found that addition of $1 \%$ oregano herb (having $1.22 \%$ carvacrol and $0.07 \%$ thymol) $\& 200 \mathrm{mg} / \mathrm{kg}$ oregano essential oil was equally effective in delaying lipid oxidation. The advantageous effects of thyme leaves supplementation in poultry vary markedly by the herb essential oil composition and the dosage used. The essential oil composition of the thyme leaf along with the type and amount of other bioactive substances present within differs depending on the thyme varieties and the region where it is grown. Therefore, it is very difficult to interpret the results without taking into consideration the composition of the thyme leaves used in the animal trials. However, in the studies conducted so far with laying hens $(11,28)$, no information was present regarding thyme leave composition. Therefore this situation prompted us to investigate the use thyme leaves (Thymus vulgaris $\mathrm{L}$.) with determined essential oil composition as a feed additive in laying hens and evaluate its effects on performance parameters as well as egg quality characteristics, egg yolk lipid composition and oxidation stability, humoral immunity and some blood parameters.

\section{Material and methods}

This study was performed by the Department of Animal Nutrition and Nutritional Diseases of Veterinary Faculty in Ankara University (Turkey). The experimental procedures were approved by the Ankara University Animal Ethics Committee (2015-1-4).

Experimental design and preparation of feeds: A random allocation of 108 Hyline Brown laying hens aged 36 weeks into three groups ( 6 replicates each, 6 hens per replicate) was conducted. The experiment lasted for a period of 16 weeks. Dried and ground thyme leaves (Thymus vulgaris $\mathrm{L}$.) were added in the diets at the levels of 0 (control), 1 and 2\%. Isocaloric and isonitrogenous diets were formulated to meet the minimum requirements of Hyline Brown laying hen in the catalogue (33). The formulation and nutrient composition of the diets were given in Table 1. Feed (mash) and water were provided ad libitum.

Analysis of dried thyme leaves and feeds: Nutrient composition of dried thyme leaves and feeds were analyzed (6). Calcium (25), total phosphorus (3) and metabolizable energy levels (16) of diets were determined.

The essential oil composition of dried thyme leaves was analyzed with GC-MS (Agilent-6890, MS:5973, New Jersey, USA) using a HP-5 MS 30m column.

Laying hen experiment: Eggs were collected daily and egg weight was determined by individually weighing eggs laid during the last two consecutive days of every week. Egg production was expressed on a hen-day basis. Biweekly feed intake was determined as g per day per hen. The feed conversion ratio (FCR) was estimated as g feed intake per g egg produced. Hens were monitored daily.

Egg analysis: To determine the egg quality characteristics (external and internal), 60 eggs laid at 09:00 to 12:00 $\mathrm{h}$ were randomly collected from each group (10 eggs/replicate) during the last three consecutive days of last week. After weighing, egg shape index, shell breaking strength and thickness, the length, width and height of the albumen as well as the height and diameter 
Table 1. Ingredients and chemical composition of the diets (\%).

\begin{tabular}{|c|c|c|c|}
\hline \multirow{3}{*}{ Ingredients } & \multicolumn{3}{|c|}{ Dietary treatments } \\
\hline & \multicolumn{3}{|c|}{ Thyme supplementation (\%) } \\
\hline & $\mathbf{0}$ & 1 & 2 \\
\hline Corn & 54.40 & 55.53 & 56.53 \\
\hline Barley & 6.00 & 4.00 & 1.90 \\
\hline Soybean meal $(46.7 \% \mathrm{CP})$ & 15.30 & 15.40 & 15.40 \\
\hline Fullfat soya & 9.53 & 9.50 & 9.60 \\
\hline Fish meal & 3.00 & 3.00 & 3.00 \\
\hline Thyme & 0.0 & 1.00 & 2.00 \\
\hline Limestone & 9.20 & 9.20 & 9.20 \\
\hline Dicalcium phosphate & 1.60 & 1.60 & 1.60 \\
\hline Salt & 0.27 & 0.27 & 0.27 \\
\hline DL-methionine & 0.20 & 0.20 & 0.20 \\
\hline Lysine & 0.05 & 0.05 & 0.05 \\
\hline Vitamin mineral premix $^{1}$ & 0.25 & 0.25 & 0.25 \\
\hline \multicolumn{4}{|c|}{ Chemical composition, Analyzed } \\
\hline $\mathrm{ME}(\mathrm{kcal} / \mathrm{kg})^{2}$ & 2800 & 2810 & 2812 \\
\hline Crude protein $(\%)$ & 17.62 & 17.65 & 17.62 \\
\hline Calcium (\%) & 4.08 & 4.12 & 4.10 \\
\hline Total phosphorus (\%) & 0.72 & 0.74 & 0.70 \\
\hline
\end{tabular}

${ }^{1}$ Supplied per kilogram of diet: $12000000 \mathrm{IU}$ vitamin A, $2400000 \mathrm{IU}$ vitamin $\mathrm{D}_{3}, 30 \mathrm{~g}$ vitamin $\mathrm{E}, 2.5 \mathrm{~g}$ vitamin $\mathrm{K}_{3}, 2.5 \mathrm{~g}$ vitamin $\mathrm{B}_{1}$, $6 \mathrm{~g}$ vitamin $\mathrm{B}_{2}, 4 \mathrm{~g}$ vitamin $\mathrm{B}_{6}, 20 \mathrm{mg}$ vitamin $\mathrm{B}_{12}$, $25 \mathrm{~g}$ niacin, $8 \mathrm{~g}$ calcium-D-panthotenate, $1 \mathrm{~g}$ folic acid, $50 \mathrm{~g}$ vitamin $\mathrm{C}, 50 \mathrm{mg}$ Dbiotin, $150 \mathrm{~g}$ choline chloride, $1.5 \mathrm{~g}$ canthaxanthin, $0.5 \mathrm{~g}$ apo carotenoic acid esther, $80 \mathrm{~g} \mathrm{Mn}, 60 \mathrm{~g} \mathrm{Zn}, 60 \mathrm{~g} \mathrm{Fe}, 5 \mathrm{~g} \mathrm{Cu}, 1 \mathrm{~g} \mathrm{I}, 0.5 \mathrm{~g} \mathrm{Co}$, $0.15 \mathrm{~g} \mathrm{Se}$.

${ }^{2}$ Metabolizable energy content of diets was estimated according to the equation of Carpenter and Clegg (16).

of yolk were measured as shown in the study of Yalçin et al. (52). Albumen and yolk indexes and Haugh units were estimated (52).

For determination of yolk cholesterol, 12 eggs per group (2 eggs from each replicate) were randomly chosen and cholesterol levels in yolk were calculated and expressed as mg per $\mathrm{g}$ of yolk $(50,52)$.

Malondialdehyde levels in yolks of eggs (12 eggs/group, 2 eggs/replicate) collected at the 15th week of the study were determined after one-day storage (at room temperature) using commercial reagents (ImmuChrom $\mathrm{GmbH}$, Heppenheim, Germany) by HPLC system (Agilent 1100, Waldbronn, Germany) with fluorescencedetector, HPLC column (IC1900rp).

Fatty acid methyl esters (FAMEs) in egg yolk were determined as shown in the study of Yalçın et al. (51) as a percentage (w/w) of total FAMEs.

Humoral immunity: At the $16^{\text {th }}$ week of the study anti SRBC antibody titers were analyzed using 12 hens from each group. Results were given as the $\log _{2}$ of the reciprocal of the serum dilution as described by Onbaşılar and Aksoy (45).

Blood serum analysis: At the end of the experiment, blood samples were collected from the wing vein (12 birds/group, 2 birds/replicate) and serum was obtained by centrifuging at $3000 \mathrm{x} \mathrm{g}$ for $10 \mathrm{~min}$. Total protein, triglyceride and cholesterol in serum were analyzed by an automatic analyzer (BT 3000, Biotechnica Instruments, Italy) using commercial kits of Randox RX series (Randox Laboratories Ltd., London, United Kingdom).

Statistical analyses: Data were analyzed using SPSS version 23.0 for Windows software (SPSS Inc., Chicago, IL). Normal distribution was tested using the Kolmogorov-Smirnov test. One-way ANOVA was used to determine the effects of the supplementation of dried thyme leaves on different parameters and comparisons among means were done by the Tukey test. Polynomial contrasts were used to determine the linear and quadratic effects of supplementation of dried thyme leaves on different parameters. Statistical differences were considered significant at $\mathrm{P} \leq 0.05$ (19).

\section{Results}

Dried thyme leaves had (\%) 91.65 dry matter, 8.3 crude protein, 2 crude fibre, 4.5 ether extract, 3.9 crude ash. The essential oil of dried thyme leaves was rich in carvacrol (54.7 g/100 g essential oil) and 4'methylacetophenone p-cymene $(37.34 \mathrm{~g} / 100 \mathrm{~g}$ essential oil) as shown in Table 2.

Supplementation of thyme leaves to the diets didn't affect feed intake, hen-day egg production, egg weight and feed conversion ratio as shown in Table 3. No linear and quadratic effects were seen between the performance parameters and thyme dose levels. 
Table 2. Essential oil composition of dried thyme leaves.

\begin{tabular}{ll}
\hline Ingredients & g/100g essential oil \\
\hline Carvacrol & 54.70 \\
4'-Methylacetophenone p-cymene & 37.34 \\
Alpha-pinene & 1.83 \\
Camphene & 1.54 \\
Myrcene & 0.96 \\
Alpha-terphinene & 0.42 \\
Gamma-terpinene & 0.92 \\
Isoborneol (Isomer 2) & 0.86 \\
4-Carvomenthenol; terpinene-4-ol & 0.39 \\
2-Isopropyl-5-methylbenzoquinone & 0.98 \\
Caryophyllene & 0.68 \\
Alpha-caryophyllene & 0.30 \\
\hline
\end{tabular}

Table 3. The effects of dietary thyme on the performance of laying hens.

\begin{tabular}{|c|c|c|c|c|c|c|c|}
\hline & \multicolumn{3}{|c|}{ Thyme (\%) } & \multirow{2}{*}{$\begin{array}{c}\text { Pooled } \\
\text { SEM }\end{array}$} & \multicolumn{3}{|c|}{ Significance } \\
\hline & $\mathbf{0}$ & 1 & 2 & & Combine & Linear & Quadratic \\
\hline FI (g) & 107.9 & 107.3 & 109.1 & 0.374 & 0.107 & 0.157 & 0.105 \\
\hline $\operatorname{HD} \operatorname{EP}(\%)$ & 82.36 & 81.86 & 82.69 & 0.596 & 0.864 & 0.831 & 0.626 \\
\hline EW (g) & 63.03 & 62.96 & 63.16 & 0.153 & 0.873 & 0.740 & 0.695 \\
\hline FCR ( $g$ feed/g egg) & 2.08 & 2.08 & 2.09 & 0.015 & 0.944 & 0.752 & 0.915 \\
\hline
\end{tabular}

No significant differences among groups.

FI: feed intake, HD EP: hen-day egg production, EW: egg weight, FCR: feed conversion ratio.

Table 4. The effects of dietary thyme leaves on egg traits and egg part percentages.

\begin{tabular}{|c|c|c|c|c|c|c|c|}
\hline & \multicolumn{3}{|c|}{ Thyme (\%) } & \multirow{2}{*}{$\begin{array}{l}\text { Pooled } \\
\text { SEM }\end{array}$} & \multicolumn{3}{|c|}{ Significance } \\
\hline & $\mathbf{0}$ & 1 & 2 & & Combine & Linear & Quadratic \\
\hline SI $(\%)$ & 75.22 & 76.01 & 75.40 & 0.162 & 0.117 & 0.982 & 0.072 \\
\hline $\mathrm{BS}\left(\mathrm{kg} / \mathrm{cm}^{2}\right)$ & 2.84 & 2.83 & 2.75 & 0.039 & 0.661 & 0.898 & 0.753 \\
\hline $\mathrm{ST}(\mu \mathrm{m})$ & 366.7 & 366.4 & 357.4 & 0.494 & 0.694 & 0.733 & 0.751 \\
\hline $\mathrm{AH}(\mathrm{mm})$ & 6.82 & 6.78 & 6.80 & 0.039 & 0.914 & 0.579 & 0.691 \\
\hline $\mathrm{AI}(\%)$ & 8.50 & 8.58 & 8.54 & 0.067 & 0.901 & 0.485 & 0.710 \\
\hline YI (\%) & 43.56 & 43.64 & 42.53 & 0.324 & 0.228 & 0.926 & 0.471 \\
\hline HU (\%) & 81.22 & 81.05 & 81.18 & 0.239 & 0.965 & 0.914 & 0.795 \\
\hline SW (\%) & 10.31 & 10.36 & 10.32 & 0.038 & 0.873 & 0.902 & 0.618 \\
\hline $\mathrm{AW}(\%)$ & 66.35 & 65.94 & 65.90 & 0.293 & 0.809 & 0.563 & 0.781 \\
\hline YW (\%) & 23.34 & 23.70 & 23.78 & 0.305 & 0.842 & 0.589 & 0.838 \\
\hline
\end{tabular}

No significant differences among groups.

SI: shape index, BS: breaking strength, ST: shell thickness, AH: albumen height, AI: albumen index, YI: yolk index, HU: haugh unit, SW: shell weight, AW: albumen weight, YW: yolk weight

Dietary thyme supplementation had no significant effect on egg shape index, egg breaking strength, shell thickness, egg albumen height, albumen index, yolk index, Haugh unit and the weight percentages of egg yolk, albumen and shell (Table 4). Also, no linear relationship of thyme dose levels was observed for these egg quality parameters. Linear effects $(\mathrm{P}<0.001)$ of thyme doses with yolk MDA concentration were seen (Table 5). A linear reduction in 16:0 while a linear increase in 18:2n-6 and 18:3n-3 of yolk fatty acids were observed with increasing thyme leaves supplementation $(\mathrm{P}<0.001)$ as shown in Table 6 . The ratio of total saturated fatty acids (SFA)/total unsaturated fatty acids (UFA) in egg yolk was reduced significantly $(\mathrm{P}<0.001)$.

There were no significant differences in the blood serum protein, however blood serum cholesterol and triglyceride levels were decreased $(\mathrm{P}<0.05)$ by $2 \%$ thyme inclusion (Table 7). A linear relationship of dietary thyme level was seen with blood cholesterol and blood triglyceride $(\mathrm{P}<0.001)$. Antibody titers against SRBC were improved $(\mathrm{P}=0.010)$ in the group consuming $2 \%$ thyme (Table 7). A linear increase was seen in antibody titers against $\mathrm{SRBC}(\mathrm{P}=0.005)$ with an increase in thyme dose. 
Table 5. The effects of dietary thyme leaves on cholesterol and MDA levels in egg yolk.

\begin{tabular}{|c|c|c|c|c|c|c|c|}
\hline & \multicolumn{3}{|c|}{ Thyme (\%) } & \multirow{2}{*}{$\begin{array}{l}\text { Pooled } \\
\text { SEM }\end{array}$} & \multicolumn{3}{|c|}{ Significance } \\
\hline & $\mathbf{0}$ & 1 & 2 & & Combine & Linear & Quadratic \\
\hline Cholesterol (mg/g) & $12.52^{\mathrm{a}}$ & $11.88^{\mathrm{b}}$ & $11.10^{\mathrm{c}}$ & 0.147 & $<0.001$ & $<0.001$ & 0.476 \\
\hline MDA (ng/g) & $34.41^{\mathrm{a}}$ & $32.23^{\mathrm{a}}$ & $25.73^{\mathrm{b}}$ & 1.060 & $<0.001$ & $<0.001$ & 0.114 \\
\hline
\end{tabular}

a,b,c: Means within a row followed by the different superscripts differ significantly $(\mathrm{P}<0.05)$.

Table 6. The effects of dietary thyme leaves on yolk fatty acids (\% of total methyl esters of fatty acids) of laying hens.

\begin{tabular}{|c|c|c|c|c|c|c|c|}
\hline & \multicolumn{3}{|c|}{ Thyme (\%) } & \multirow[t]{2}{*}{ Pooled SEM } & \multicolumn{3}{|c|}{ Significance } \\
\hline & $\mathbf{0}$ & 1 & 2 & & Combine & Linear & Quadratic \\
\hline 14:0 & 0.357 & 0.340 & 0.328 & 0.005 & 0.090 & 0.031 & 0.812 \\
\hline $16: 0$ & $26.382^{\mathrm{a}}$ & $24.547^{\mathrm{ab}}$ & $22.513^{b}$ & 0.490 & 0.001 & $<0.001$ & 0.888 \\
\hline $16: 1 n-7$ & 3.270 & 3.243 & 3.512 & 0.107 & 0.557 & 0.382 & 0.535 \\
\hline $17: 0$ & 0.345 & 0.338 & 0.340 & 0.006 & 0.892 & 0.735 & 0.744 \\
\hline 18:0 & 9.290 & 8.400 & 8.303 & 0.193 & 0.062 & 0.032 & 0.291 \\
\hline 18:1n-9 & 39.167 & 40.170 & 39.602 & 0.285 & 0.377 & 0.542 & 0.213 \\
\hline $18: 2 n-6$ & $15.377^{\mathrm{c}}$ & $16.643^{\mathrm{b}}$ & $19.038^{\mathrm{a}}$ & 0.398 & $<0.001$ & $<0.001$ & 0.119 \\
\hline 20:0 & 0.472 & 0.505 & 0.472 & 0.028 & 0.872 & 0.890 & 0.606 \\
\hline $18: 3 n-3$ & $0.348^{\mathrm{b}}$ & $0.403^{\mathrm{b}}$ & $0.507^{\mathrm{a}}$ & 0.021 & 0.001 & $<0.001$ & 0.437 \\
\hline $20: 1 n-11$ & 0.105 & 0.108 & 0.110 & 0.003 & 0.790 & 0.507 & 0.898 \\
\hline $20: 4 n-6$ & 1.290 & 1.390 & 1.435 & 0.030 & 0.124 & 0.048 & 0.646 \\
\hline $22: 0$ & 2.397 & 2.418 & 2.165 & 0.064 & 0.213 & 0.147 & 0.312 \\
\hline $20: 3 n-3$ & 0.363 & 0.465 & 0.545 & 0.033 & 0.070 & 0.024 & 0.865 \\
\hline $22: 5 n-3$ & 0.425 & 0.527 & 0.565 & 0.027 & 0.080 & 0.032 & 0.545 \\
\hline $22: 6 n-3$ & 0.413 & 0.502 & 0.565 & 0.030 & 0.110 & 0.039 & 0.833 \\
\hline$\sum$ SFA & $39.242^{\mathrm{a}}$ & $36.548^{b}$ & $34.122^{c}$ & 0.613 & $<0.001$ & $<0.001$ & 0.866 \\
\hline$\sum \mathrm{UFA}$ & $60.758^{c}$ & $63.452^{\mathrm{b}}$ & $65.878^{a}$ & 0.613 & $<0.001$ & $<0.001$ & 0.866 \\
\hline$\sum$ MUFA & 42.542 & 43.522 & 43.223 & 0.292 & 0.397 & 0.356 & 0.319 \\
\hline$\sum$ PUFA & $18.217^{\mathrm{c}}$ & $19.930^{\mathrm{b}}$ & $22.655^{\mathrm{a}}$ & 0.472 & $<0.001$ & $<0.001$ & 0.186 \\
\hline$n-3$ & $1.187^{\mathrm{b}}$ & $1.432^{\mathrm{ab}}$ & $1.637^{\mathrm{a}}$ & 0.064 & 0.006 & 0.002 & 0.848 \\
\hline$n-6$ & 14.865 & 13.376 & 13.288 & 0.493 & 0.362 & 0.209 & 0.511 \\
\hline$\sum \mathrm{SFA} / \sum \mathrm{UFA}$ & $0.647^{\mathrm{a}}$ & $0.577^{\mathrm{b}}$ & $0.519^{c}$ & 0.015 & $<0.001$ & $<0.001$ & 0.771 \\
\hline$n-3 / n-6$ & 0.084 & 0.111 & 0.127 & 0.008 & 0.075 & 0.026 & 0.741 \\
\hline$n-6 / n-3$ & 13.151 & 9.646 & 8.373 & 0.880 & 0.062 & 0.024 & 0.509 \\
\hline
\end{tabular}

a,b,c: Means within a row followed by the different superscripts differ significantly $(\mathrm{P}<0.05)$.

$\sum$ SFA: total saturated fatty acids, $\sum$ UFA: total unsaturated fatty acids, $\sum$ MUFA: total mono unsaturated fatty acids, $\sum$ PUFA: total poly unsaturated fatty acids, n-3: omega-3 fatty acids, n-6: omega- 6 fatty acids.

Table 7. The effects of dietary thyme leaves on anti SRBC titer and some blood serum parameters in laying hens.

\begin{tabular}{|c|c|c|c|c|c|c|c|}
\hline & \multicolumn{3}{|c|}{ Thyme (\%) } & \multirow{2}{*}{$\begin{array}{c}\text { Pooled } \\
\text { SEM }\end{array}$} & \multicolumn{3}{|c|}{ Significance } \\
\hline & $\mathbf{0}$ & 1 & 2 & & Combined & Linear & Quadratic \\
\hline Anti SRBC titer $\left(\log _{2}\right)$ & $5.17^{\mathrm{b}}$ & $5.33^{\mathrm{b}}$ & $6.67^{\mathrm{a}}$ & 0.240 & 0.010 & 0.005 & 0.163 \\
\hline Protein $(g / l)$ & 46.65 & 47.88 & 47.80 & 0.293 & 0.160 & 0.110 & 0.279 \\
\hline Cholesterol (g/l) & $1.55^{\mathrm{a}}$ & $1.49^{\mathrm{a}}$ & $1.39^{\mathrm{b}}$ & 0.020 & $<0.001$ & $<0.001$ & 0.519 \\
\hline Triglyceride (g/l) & $16.58^{\mathrm{a}}$ & $15.80^{\mathrm{a}}$ & $14.74^{\mathrm{b}}$ & 0.222 & $<0.001$ & $<0.001$ & 0.618 \\
\hline
\end{tabular}

a,b: Means within a row followed by the different superscripts differ significantly $(\mathrm{P}<0.05)$. 


\section{Discussion and Conclusion}

The essential oil of dried thyme leaves was high in carvacrol (Table 2). This value was within the range (5$75 \%$ ) reported by De Leon-Rodriguez et al. (20). The composition of the oil depends on many factors such as soil fertility, region and variety of the plant. Carvacrol has many bioactive properties including antibacterial, antioxidant, hypocholesterolemic, antiseptic, antispasmodic, growth promoter, anti-inflammatory, antifungal, antiviral, expectorant, antitussive, immunomodulatory and chemopreventive $(4,15,29,40)$.

Dietary thyme leaves didn't affect the performance parameters (Table 3). Other authors $(7,18,21,28)$ also reported similar results for feed intake, egg production, egg weight and FCR when animal diets were supplemented with thyme leaves, essential thyme oil and essential oregano oil. The addition of oregano oil (26) and thyme oil (14) to the diets had no significant effect on FCR in laying hens. Contrarily, He et al. (30) showed that egg production, average egg weight and feed efficiency were significantly improved in the group consuming a diet supplemented $100 \mathrm{mg} / \mathrm{kg}$ oregano essential oils. Bölükbaşı et al. (14) also indicated that dietary supplementation of mixed essential oils and thyme oil increased the egg production. Vakili and Majidzadeh Heravi (49) found that egg production, feed intake and FCR were not significantly affected by thyme extract but egg weight and egg mass values were improved. Karimi et al. (34) also observed that supplementation of different oregano levels and sources had no effect on FCR in broilers. Manafi et al. (42) reported that egg production and FCR with dietary phytogenic feed additive containing thymol and carvacrol showed significant improvement, however, egg weight and feed consumption values remained statistically non-significant. Ali et al. (5) observed that thyme supplementation improved egg production and FCR. The results of many studies about the performance of poultry supplemented with thyme and its essential oils were inconsistent. The reason for the different effects on performance may be due to the type and dose of essential oil, variety of thyme, composition of essential oil, the composition of the basal diet, environmental conditions and their utilization in poultry $(21,29)$

In the present study dietary thyme did not significantly affect egg shape index, egg breaking strength, shell thickness, egg albumen height, albumen index, yolk index and Haugh unit (Table 4). It was in agreement with other studies, in which supplementation of thyme and essential oils also had no effect on egg shape index (26), egg breaking strength $(18,21)$, eggshell thickness $(5,18,26,42)$, eggshell weight $(5,18,30,49)$, yolk index (49), albumen height (21) and Haugh unit (21,
26). Contrarily, in some studies eggshell strength $(42,49)$, eggshell weight (42) and Haugh unit values (49) were improved.

Various sources such as herbs, microalgae, flaxseed, fish oil are used to improve shelf-life, enrich healthbeneficial fatty acids and decrease cholesterol content in eggs. In this study the yolk MDA concentration of eggs decreased $(\mathrm{P}<0.001)$ with $2 \%$ thyme supplementation (Table 5). Linear effect $(\mathrm{P}<0.001)$ of thyme dose on yolk MDA reduction was seen. Similarly, Botsoglou et al. (13) reported that thyme treatment reduced oxidation of liquid yolk. Some researchers also observed that supplementation of diets with essential oils lowered MDA concentration in the yolk (35) and in the thigh muscle, liver and serum in broilers (29). The phenolic compound found in thyme, carvacrol, plays a critical role as a natural antioxidant in the reduction of lipid peroxidation which can cause oxidative destruction of cellular membranes $(4,53)$. The polyunsaturated fatty acids (PUFA) are the components most susceptiple to oxidation processes, thus leading to lipid oxidation in meat. The antioxidant activity of thymol and carvacrol was thought to prevent peroxidation of thigh lipids, especially PUFA (29).

In this study thyme leaves supplementation resulted in a decrease $(\mathrm{P}<0.001)$ of egg yolk cholesterol (Table 5). Linear effect $(\mathrm{P}<0.001)$ was observed between thyme supplementation levels and yolk cholesterol. Similar results were observed by Vakili and Majidzadeh Heravi (49) with thyme extract. This reduction may be related to the active components of thyme. These components may reduce the liver enzyme activity of 3-hydroxy-3methylglutaryl coenzyme A reductase, which is a key enzyme in cholesterol synthesis $(1,46,49)$. The egg is a very good food product to enrich with omega-3 (n-3) fatty acids. The fatty acid profile of the egg yolk is closely related to the feed lipids consumed by the laying hens. In the present study, linoleic acid in yolk was increased significantly $(\mathrm{P}<0.001)$ by thyme supplementation (Table 6 ). Dietary thyme at $2 \%$ resulted in an increase in $\alpha$ linolenic acid while it decreased palmitic acid percentage in the yolk $(\mathrm{P}=0.001)$. Linear effects were seen between these fatty acids and doses of thyme supplementation $(\mathrm{P}<0.001)$. Such linear increment effects were also observed between yolk fatty acids percentages of eicosatrienoic acid (20:3n-3), DPA (22:5n-3) and DHA (22:6n-3) with dietary thyme doses $(\mathrm{P}<0.05)$. Total SFA and the ratio of SFA/UFA were decreased and total UFA were increased $(\mathrm{P}<0.001)$ with thyme supplementation. $\mathrm{n}$ 3 fatty acids and $n-3 / n-6$ ratio were increased by $2 \%$ thyme. Linear effects between these fatty acids and thyme doses were seen $(\mathrm{P}<0.05)$. The increase in PUFA and a decrease in SFA content in egg yolk may be due to the hypolipidemic and antioxidant properties of bioactive 
compounds especially carvacrol in thyme. Similarly, Vakili and Majidzadeh Heravi (49) also found that palmitic acid decreased and linolenic acid increased in egg yolk with thyme extract supplementation. Hashemipour et al. (29) also reported in broilers that dietary thymol+carvacrol supplementation modified the fatty acid composition of serum and thigh muscle by reducing total SFA and increasing total PUFA and n-6 fatty acids in serum and thigh and increasing total monounsaturated fatty acids (MUFA) in the thigh. The $n-3$ fatty acids in serum and thigh were not affected by the inclusion and level of the thymol+carvacrol (29). Ding et al. (21) indicated a non-significant decrease in SFA and MUFA with an increment in PUFA in yolk by supplementation of an essential oil product containing thymol during 12 weeks trial.

In the present study, no significant differences were seen in the blood serum protein, however blood serum triglyceride and cholesterol levels were decreased $(\mathrm{P}<0.05)$ by $2 \%$ thyme inclusion (Table 7$)$. There was a linear relationship of dietary thyme level with blood cholesterol and blood triglyceride $(\mathrm{P}<0.001)$. These results could be attributed to some hypocholesterolemic and antilipidemic effects due to the action of carvacrol in thyme on HMG-CoA reductase which could reduce the absorption of fat from the gut or the lipid catabolism for gluconeogenesis $(1,23,36)$. Similarly, some researchers $(5,23,42)$ reported that thyme and other phytogenic feed additive supplementation decreased blood cholesterol and triglycerides in poultry. Radwan et al. (46) reported that the addition of $1 \%$ thyme to broiler diets significantly decreased the plasma total lipids. Plant derivatives, carvacrol significantly reduce triglycerides in poultry blood $(1,9,38,42)$. The lipophilic property and chemical structure of phenolic compounds in phytogenic substances may be important in the manipulation of the enzyme activities in the body. Terpenoids and phenylpropanoids can penetrate the membranes of the bacteria and reach the inner part of the cell of poultry (10). Increased lipid digestibility due to a higher secretion of bile and digestive enzymes might have resulted in low serum cholesterol, thus, improving nutrient supply and transport (41). In contrast to the study El-Ghousein and Al-Beitawi (23) reported that the total protein levels in serum were significantly increased by thyme supplementation. Lee et al. (37) also stated that dietary supplementation of carvacrol and thymol caused no differences on cholesterol levels.

The prevention of infectious diseases in poultry production is of great significance. Various factors including failure in vaccination, immune-suppressive diseases, and exorbitant use of antibiotics can induce immunodeficiency. Herbs such as thyme rich in flavonoids, can extend the activity of vitamin C, thus, act as antioxidants and consequently improve immune functions (2, 29). Because of antibacterial, antiviral and antioxidant properties of thymol and carvacrol, improvements in immune responses of chicks are anticipated (12). Acamovic and Brooker (2) stated the stimulation of cellular and humoral immunity due to polyphenol fraction of thymol and oregano essential oil. In the present study, antibody titers against SRBC were improved $(\mathrm{P}=0.010)$ in the group consuming diet supplemented with $2 \%$ thyme (Table 7 ). Linear increment effects were seen between the thyme doses and antibody titers against SRBC $(\mathrm{P}=0.05)$. This high antibody titer in laying hens consuming thyme supplementary diets could be attributed to the beneficial effects of thyme in maintaining the physiological balance of immunopotent cells and therefore providing a healthy environment. However Toghyani et al. (48) showed that dietary thyme at 0.5 and $1 \%$ in the diets had no effect on antibody titer against Newcastle and influenza viruses or sheep red blood cells in broilers. The dose of thyme powder is important for its immunostimulating effect. In the present study $1 \%$ of thyme had no significant effect on anti SRBC titer. Du et al. (22) reported that dietary supplementation of 120 and $240 \mathrm{mg} / \mathrm{kg}$ essential oil significantly increased the serum NDV (Newcastle disease virus) antibody titers compared with the basal diet. Some researchers also demonstrated that dietary supplementation of essential oils enhanced the specific immune responses in broilers $(8,47)$. Hashemipour et al. (29) observed improvement in cellular and humoral immune responses caused by the dietary inclusion of thymol+carvacrol which increased the primary and secondary response against SRBC and IgG.

Differences in species, age \& sex of the poultry, ingredients \& nutrient composition of diet, dose $\&$ species of herb or its extract might be the reasons behind discrepancies between some of the results of the present study and the studies reported previously. Therefore it is required to conduct more detailed research to clarify the effects and mechanism of thyme usage in poultry.

It can be concluded that thyme at $1 \%$ and $2 \%$ in the diets of laying hens had no effects on performance and egg traits. The supplementation of thyme as herb was beneficial in lowering egg yolk cholesterol and increasing omega-3 fatty acids in egg yolk. It shows the excellent potential of thyme for the development of functional eggs. Thyme supplementation might also be helpful in improving the antioxidant status and humoral immune response in the birds as well as in the treatment of hyperlipidemic conditions. Thus, commercially, dried thyme leaves can be used to produce nutritionally modified eggs as functional foods that are low in cholesterol and rich in omega-3 fatty acids. 


\section{Financial Support}

This research received no grant from any funding agency/sector.

\section{Ethical Statement}

This study was approved by the Ankara University Animal Ethics Committee (2015-1-4).

\section{Conflict of Interest}

The authors declare that they have no conflict of interest.

\section{References}

1. Abdulkarimi R, Daneshyar M, Aghazadeh A (2011): Thyme (Thymus vulgaris) extract consumption darkens liver, lowers blood cholesterol, proportional liver and abdominal fat weights in broiler chickens. Ital J Anim Sci, 10, 101-105.

2. Acamovic T, Brooker JD (2005): Biochemistry of plant secondary metabolites and their effects in animals. Proc Nutr Soc, 64, 403-412.

3. ADAS (1981): The Analysis of Agricultural Materials. 2nd ed. Ministry of Agriculture, Fisheries and Food, Agricultural Development and Advisory Service, Her Majesty's Stationery Office, London, UK.

4. Alagawany M, Abd El-Hack ME, Farag MR, et al (2015): Biological effects and modes of action of carvacrol in animal and poultry production and health $-A$ review. Adv Anim Vet Sci, 3, 73-84.

5. Ali MN, Hassan MS, Abd El-Ghany FA (2007): Effect of strain, type of natural antioxidant and sulphate ion on productive, physiological and hatching performance of native laying hens. Int J Poult Sci, 6, 539-554.

6. AOAC (2000): Official Methods of Analysis of the Association of Official Analytical Chemists. 17th ed. AOAC International, Maryland, USA.

7. Arpášová H, Gálik B, Hrnčár C, et al (2015): The effect of essential oils on performance of laying hens. Anim Sci Biotechnol, 48, 8-14.

8. Awaad MHH, Elmenawey M, Ahmed KA (2014): Effect of a specific combination of carvacrol, cinnamaldehyde, and Capsicum oleoresin on the growth performance, carcass quality and gut integrity of broiler chickens. Vet World, 7, 284-290.

9. Babazadeh D, Vahdatpour T, Nikpiran H, et al (2011): Effects of probiotic, prebiotic and synbiotic intake on blood enzymes and performance of Japanese quails (Coturnix Japonica). Indian J Anim Sci, 81, 106-110.

10. Bhatt N (2015): Herbs and herbal supplements, a novel nutritional approach in animal nutrition. Iran J Appl Anim Sci, 5, 497-516.

11. Botsoglou NA, Florou-Paneri $P$, Botsoglou $E$, et al (2005): The effect offeeding rosemary, oregano, saffron and $\alpha$-tocopheryl acetate on hen performance and oxidative stability of eggs. South African J Anim Sci, 35, 143-151.

12. Botsoglou NA, Florou-Paneri P, Christaki E, et al (2002): Effect of dietary oregano essential oil on performance of chickens and on iron-induced lipid oxidation of breast, thigh and abdominal fat tissues. $\mathrm{Br}$ Poult Sci, 43, 223-230.

13. Botsoglou NA, Yannakopoulos AL, Fletouris DJ, et al (1997): Effect of dietary thyme on the oxidative stability of egg yolk. J Agric Food Chem, 45, 3711-3716.

14. Bölükbaşı ŞC, Erhan MK, Kaynar Ö (2008): The effect of feeding thyme, sage and rosemary oil on laying hen performance, cholesterol and some proteins ratio of egg yolk and Escherichia coli count in feces. Arch fur Geflugelkd, 72, 231-237.

15. Bravo D, Pirgozliev V, Rose SP (2014): A mixture of carvacrol, cinnamaldehyde, and capsicum oleoresin improves energy utilization and growth performance of broiler chickens fed maize-based diet. J Anim Sci, 92, 1531-1536.

16. Carpenter KJ, Clegg KM (1956): The metabolizable energy of poultry feeding stuffs in relation to their chemical composition. J Sci Food Agric, 7, 45-51.

17. Chen Y, Chen H, Li W, et al (2018): Polyphenols in Eucalyptus leaves improved the egg and meat qualities and protected against ethanol-induced oxidative damage in laying hens. J Anim Physiol Anim Nutr (Berl), 102, 214223.

18. Çufadar Y (2018): Effects of dietary oregano essential oil supplementation on performance and eggshell quality in laying hens. Selcuk J Agric Food Sci, 32, 158-161.

19. Dawson B, Trap RG (2001): Basic and Clinical Biostatistics, Division, Lange Medical Books/McGraw-Hill Medical Publishing, New York.

20. De Leon-Rodriguez A, Escalante-Minakata P, JimenezGarcia MI, et al (2008): Characterization of volatile compounds from ethnic Agave alcoholic beverages by gas chromatography-mass spectrometry. Food Technol Biotechnol, 46, 448-455.

21. Ding X, Yu Y, Su Z, et al (2017): Effects of essential oils on performance, egg quality, nutrient digestibility and yolk fatty acid profile in laying hens. Anim Nutr, 3, 127-131.

22. Du E, Wang W, Gan L, et al (2016): Effects of thymol and carvacrol supplementation on intestinal integrity and immune responses of broiler chickens challenged with Clostridium perfringens. J Anim Sci Biotechnol, 7, 1-10.

23. El-Ghousein SS, Al-Beitawi NA (2009): The effect of feeding of crushed thyme (Thymus valgaris $L$ ) on growth, blood constituents, gastrointestinal tract and carcass characteristics of broiler chickens. J Poult Sci, 46, 100-104.

24. Fachini-Queiroz FC, Kummer R, Estevão-Silva CF, et al (2012): Effects of thymol and carvacrol, constituents of Thymus vulgaris L. essential oil, on the inflammatory response. Evid Based Complement Alternat Med, 2012, 657026.

25. Farese G, Schmidt JL, Mager M (1967): An automated method for the determination of serum calcium with glyoxal bis (2-hydroxyanil). Clin Chem, 13, 515-520.

26. Florou-Paneri P, Nikolakakis I, Giannenas I, et al (2005a): Hen performance and egg quality as affected by dietary oregano essential oil and $\alpha$-tocopheryl acetate supplementation. Int J Poult Sci, 4, 449-454.

27. Florou-Paneri P, Palatos G, Govaris A, et al (2005b): Oregano herb versus oregano essential oil as feed supplements to increase the oxidative stability of turkey meat. Int J Poult Sci, 4, 866-871. 
28. Ghasemi R, Zarei M, Torki M, et al (2010): Adding medicinal herbs including garlic (Allium sativum) and thyme (Thymus vulgaris) to diet of laying hens and evaluating productive performance and egg quality characteristics. Am J Anim Vet Sci, 5, 151-154.

29. Hashemipour H, Kermanshahi H, Golian A, et al (2013): Metabolism and nutrition: Effect of thymol and carvacrol feed supplementation on performance, antioxidant enzyme activities, fatty acid composition, digestive enzyme activities, and immune response in broiler chickens. Poult Sci, 92, 2059-2069.

30. He X, Hao D, Liu C, et al (2017): Effect of supplemental oregano essential oils in diets on production performance and relatively intestinal parameters of laying hens. Am J Mol Biol, 7, 73-85.

31. Hernández F, Madrid J, García V, et al (2004): Influence of two plant extracts on broilers performance, digestibility, and digestive organ size. Poult Sci, 83, 169-174.

32. Hosseinzadeh S, Jafarikukhdan A, Hosseini A, et al (2015): The application of medicinal plants in traditional and modern medicine: A review of Thymus vulgaris. Int $\mathbf{J}$ Clin Med, 6, 635-642.

33. Hy-Line (2019): Hy-Line W-36 Commercial Layers: Management Guide. Hy-Line International, West Des Moines, IA, USA.

34. Karimi A, Yan F, Coto C, et al (2010): Effects of level and source of oregano leaf in starter diets for broiler chicks. $\mathrm{J}$ Appl Poult Res, 19, 137-145.

35. Kaya H, Kaya A, Celebi S, et al (2013): Effects of dietary supplementation of essential oils and vitamin $E$ on performance, egg quality and Escherichia coli count in excreta. Indian J Anim Res, 47, 515-520.

36. Khan RU, Naz S, Nikousefat Z, et al (2012): Thymus vulgaris: Alternative to antibiotics in poultry feed. Worlds Poult Sci J, 68, 401-408.

37. Lee KW, Everts H, Kappert HJ, et al (2003a): Effects of dietary essential oil components on growth performance, digestive enzymes and lipid metabolism in female broiler chickens. Br Poult Sci, 44, 450-457.

38. Lee KW, Everts H, Kappert HJ, et al (2003b). Dietary carvacrol lowers body weight gain but improves feed conversion in female broiler chickens. J Appl Poult Res, 12, 394-399.

39. Lemahieu C, Bruneel C, Ryckebosch E, et al (2015): Impact of different omega-3 polyunsaturated fatty acid ( $n-3$ PUFA) sources (flaxseed, Isochrysis galbana, fish oil and DHA Gold) on n-3 LC-PUFA enrichment (efficiency) in the egg yolk. J Funct Foods, 19, 821-827.

40. Luna A, Lábaque MC, Zygadlo JA, et al (2010): Effects of thymol and carvacrol feed supplementation on lipid oxidation in broiler meat. Poult Sci, 89, 366-370.

41. Manafi M (2015): Comparison study of a natural nonantibiotic growth promoter and a commercial probiotic on growth performance, immune response and biochemical parameters of broiler chicks. J Poult Sci, 52, 274-281.

42. Manafi M, Hedayati M, Khalaji S (2016): Effectiveness of phytogenic feed additive as alternative to bacitracin methylene disalicylate on hematological parameters, intestinal histomorphology and microbial population and production performance of Japanese Quails. Asian Australas J Anim Sci, 29, 1300-1308.

43. Migliorini MJ, Boiago MM, Roza LF, et al (2019): Oregano essential oil (Origanum vulgare) to feed laying hens and its effects on animal health. An Acad Bras Cienc, 91, 1-10.

44. Miura K, Nakatani N (1989): Antioxidative activity of flavonoids from thyme (Thymus vulgaris L.). Agric Biol Chem, 53, 3043-3045.

45. Onbaşılar EE, Aksoy FT (2005): Stress parameters and immune response of layers under different cage floor and density conditions. Livest Prod Sci, 95, 255-263.

46. Radwan Nadia L, Hassan RA, Qota EM, et al (2008): Effect of natural antioxidant on oxidative stability of eggs and productive and reproductive performance of laying hens. Int J Poult Sci, 7, 134-150.

47. Saei MM, Sadeghi AA, Ahmadvand H (2013): The effect of Myrtus communis oil extract on growth performance, serum biochemistry and humoral immune responses in broiler chicks fed diet containing aflatoxin B1. Arch Anim Breed, 56, 842-850.

48. Toghyani M, Tohidi M, Gheisari AA, et al (2010): Performance, immunity, serum biochemical and hematological parameters in broiler chicks fed dietary thyme as alternative for an antibiotic growth promoter. African J Biotechnol, 9, 6819-6825.

49. Vakili R, Majidzadeh Heravi R (2016): Performance and egg quality of laying hens fed diets supplemented with herbal extracts and flaxseed. Poult Sci, 4, 107-116.

50. Waldroup PW, Ndife LI, Hellwig HM, et al (1986): Influence of Probucol ((4,4'-Isopropylidine dithio)-bis(2,6di-t-butyl-phenol)) on egg yolk cholesterol content and performance of laying hens. Poult Sci, 65, 1949-1954.

51. Yalçın S, Yalçın S, Çakın K, et al (2010): Effects of dietary yeast autolysate (Saccharomyces cerevisiae) on performance, egg traits, egg cholesterol content, egg yolk fatty acid composition and humoral immune response of laying hens. J Sci Food Agric, 90, 1695-1701.

52. Yalçın S, Yalçın S, Onbaşılar İ, et al (2014): Effects of dietary yeast cell wall on performance, egg quality and humoral immune response in laying hens. Ankara Univ Vet Fak Derg, 61, 289-294.

53. Yanishlieva NV, Marinova EM, Gordon MH, et al (1999): Antioxidant activity and mechanism of action of thymol and carvacrol in two lipid systems. Food Chem, 64, 59-66. 